\title{
Biological aspects of the leafminer Liriomyza sativae (Diptera: Agromyzidae) on melon (Cucumis melo L.)
}

\author{
Aspectos biológicos da mosca minadora Liriomyza sativae (Diptera: Agromyzidae) em melão \\ (Cucumis melo L.)
}

\author{
Elton Lucio Araujo ${ }^{\mathrm{I}^{*}}$ Carlos Henrique Feitosa Nogueira ${ }^{\mathrm{I}}$ Alexandre Carlos Menezes Netto ${ }^{\mathrm{II}}$ \\ Carlos Eduardo Souza Bezerra ${ }^{\text {III }}$
}

- NOTE -

\section{ABSTRACT}

The leafminer Liriomyza sativae Blanchard is an important insect pest on melon crops in Brazil. However, the information about its biology on melon (Cucumis melo L.) is scarce. Therefore, the aim of this research was to know some biological aspects of this pest, reared on melon plants, under laboratory conditions at $25^{\circ} \mathrm{C}$. Our results showed that the biological cycle of $\boldsymbol{L}$. sativae lasts $15.9 \pm 0.04$ days (eggadult), namely: egg (2.7 \pm 0.01 days), larva (4.1 \pm 0.03 days) and pupa $(9.1 \pm 0.03$ days). The sex ratio is 0.51 and the females live (19.3 \pm 1.09 days) longer than males $(16.2 \pm 0.96$ days). These results can help in the integrated management of $\boldsymbol{L}$. sativae on melon crops and improve the systems for rearing this leafminer in laboratory.

Key words: insect pest, Cucurbitaceae, biology, semiarid.

\section{RESUMO}

A mosca-minadora Liriomyza sativae Blanchard é uma praga importante em cultivos de meloeiro (Cucumis melo L.) no Brasil. No entanto, as suas informações sobre biologia, em meloeiro, são escassas. Portanto, o objetivo deste trabalho foi conhecer alguns aspectos biológicos dessa praga, criada em plantas de meloeiro, em condições de laboratório a $25^{\circ} \mathrm{C}$. As informações obtidas mostram que o ciclo biológico de $\mathbf{L}$. sativae é de 15,9 $\pm 0,04$ dias (ovo-adulto), sendo: ovo (2,7 $\pm 0,01$ dias), larva $(4,1 \pm 0,03$ dias $)$ e pupa $(9,1 \pm 0,03$ dias $)$. A razão sexual é de 0,51 e as fêmeas vivem mais tempo (19,3 $\pm 1,09$ dias) que os machos (16,2 $\pm 0,96$ dias). Essas informações podem auxiliar na adoção de medidas de manejo integrado de L sativae em cultivos de meloeiro e melhorar os sistemas de criação da mosca minadora em laboratório.

Palavras-chave: inseto praga, Cucurbitaceae, biologia, semiárido.
Leafminers (Diptera: Agromyzidae) belonging to the species Liriomyza sativae Blanchard, Liriomyza trifolii (Burgess) and Liriomyza huidobrensis (Blanchard) are the most aggressive, causing the major losses in different cultures from New World (MURPHY \& LaSALLE, 1999; BUENO et al., 2007). In the past years, $\boldsymbol{L}$. sativae has occasioned serious problems in melon crops (Cucumis melo L.) (Cucurbitaceae) in the semiarid of Rio Grande do Norte and Ceará States (ARAUJO et al., 2007a; COSTA-LIMA et al., 2010), main melon producers from Brazil (IBGE, 2012). Leafminer females oviposit inside the leaf mesophyll of melon plants, from where the larvae hatch and feed, consuming the photosynthetic area of the leaf, originating fruits with low total soluble solids (Brix) (ARAUJO et al., 2007a). After completing their development, the larvae turn to pupae and after few days, the adults emerge, restarting the cycle (PARRELLA, 1987).

The leafminer is a holometabolic insect, being the egg and larva stages inside the leaf, the pupa stage into the soil, and the adult is free (PARRELLA, 1987). Many are the studies about the biology of Liriomyza species around the world, under different hosts (PARRELLA, 1984; LEIBEE, 1984; MILLER \& ISGER, 1985; SCHUSTER \& PATEL, 1985; PRANDO \& CRUZ, 1986). However, information about the biological aspects of $\boldsymbol{L}$. sativae in melon

'Departamento de Ciências Vegetais, Universidade Federal Rural do Semi-Árido (UFERSA), Km 47, BR 110, 59625-900, Mossoró, RN, Brasil.E-mail: elton@ufersa.edu.br.*Autor para correspondência.

"Faculdade de Ciências Agrárias e Veterinárias (FCAV), Universidade Estadual Paulista (UNESP), Jaboticabal, SP, Brasil.

IIIDepartamento de Entomologia, Universidade Federal de Lavras (UFLA), Lavras, MG, Brasil. 
plants is scarce, and like for any pest, this knowledge is important for the correct adoption of integrated management actions.

Therefore, the present study has the aim of knowing the duration of the life stages of $\boldsymbol{L}$. sativae in melon plants, as well to observe the survival of larvae and pupae, the sex ratio and adult longevity, under $25^{\circ} \mathrm{C}$.

The research was carried out at the Laboratory of Applied Entomology from the Universidade Federal Rural do Semi-Árido (UFERSA), Mossoró, Brazil. The insects used in the experiments came from the maintenance rearing of this laboratory (whose initial population was collected in melon farms from Mossoró), reared on melon plants inside acrylic cages $(50 \times 50 \times 50 \mathrm{~cm})$. The methodology adopted for rearing the insects was the same described by ARAUJO et al. (2007b). The identification of $\boldsymbol{L}$. sativae was done at ESALQ/ USP, where morphologic and molecular aspects were considered (COSTA-LIMA, 2009).

The melon plants ('Goldex' cultivar) were produced in polyethylene pots $(10 \mathrm{~cm}$ diameter $\mathrm{x} 10 \mathrm{~cm}$ height), and when they had two leaves well formed, were individualized inside plastic cages $(10 \mathrm{~cm}$ diameter $\mathrm{x} 30 \mathrm{~cm}$ height, with lateral openings covered with a nylon mesh for air circulation) and infested for three hours by ten pairs of $\boldsymbol{L}$. sativae . Immediately after infestation, plants were put individually in white trays, inside Tecnal $^{\circledR}$ climatic chambers, model $\mathrm{Te}-401$, at $25.0 \pm 1.0^{\circ} \mathrm{C}, 12$ hours photophase and $70.0 \pm 5.0 \% \mathrm{RH}$.

The duration of egg stage was obtained by observing, four times a day, the hatching larvae inside the leaves. The viability (hatchability) of egg stage wasn't estimated due to the fact that for visualizing the oviposition puncture it's necessary to remove the leaves from the plant and observe it using a stereoscope, what would interfere in the insect's development. The observations for the end of the larval stage were made every two hours, from 8:00 a.m. to 6 p.m. until all larvae leave the leaves or die. After leaving the leaves, the larvae were individualized inside glass tubes $(2.5 \mathrm{~cm}$ diameter $\mathrm{x} 8.5 \mathrm{~cm}$ height) sealed with PVC packing film, remaining there throughout pupa stage until adult emergence. The adult insects were provided daily with honey solution (10\% in distilled water) and pure distilled water. The observations for adult emergence were made the same way we did for larval stage. The survival rate for larvae and pupae were calculated as follows: Larval survival = (no pupated larvae x 100) / no total larvae; and Pupal survival $=\left(\mathrm{n}^{\circ}\right.$ emerged adults $\left.\mathrm{x} 100\right) / \mathrm{n}^{\circ}$ total pupae. The sex ratio calculation followed the formula: Sex ratio $=\mathrm{n}^{\mathrm{o}}$ females $/\left(\mathrm{n}^{\mathrm{o}}\right.$ emerged adults). Longevity for adults was calculated by observing the daily mortality, and the data were further submitted to a survival analysis (Weibull model), using the package Survival in the $\mathrm{R}^{\circledR}$ software (2011).

The average duration for the immature life stages of $\boldsymbol{L}$. sativae on melon plants at $25^{\circ} \mathrm{C}$ was: egg $(2.7 \pm 0.01$ days $)$, larva ( $4.1 \pm 0.03$ days) and pupa ( $9.1 \pm 0.03$ days). This gives a total egg-adult period of $15.9 \pm 0.04$ days. These development times are similar to the intervals described by PARRELLA (1987), for species from the genus Liriomyza. They are also similar to the duration verified by COSTA-LIMA et al. (2009) for L. sativae on Vigna unguiculata (Fabaceae) at $25^{\circ} \mathrm{C}$, with development times of 2.5 days for egg, 4.9 days for larva, 8.0 days for pupa and 16.5 days for egg-adult.

The results obtained by LANZONI et al. (2002) for $\boldsymbol{L}$. trifolii, on $\boldsymbol{V}$. unguiculata at $25^{\circ} \mathrm{C}$ - egg (2.1 days), larva (4.6 days), pupa (9.2 days) and eggadult (15.9 days) - were also similar to the results presented here. These durations differ slightly from the work of the same authors above, for L. huidobrensis also in cowpea, with 2.2 days for egg, 5.8 days for larva, 8.2 days for pupa and 16.2 days for egg-adult. The most different results from the present research were found in the work of LEIBEE (1984), in the larva stage of L. trifolii on Apium graveolens (Apiaceae), with durations of 2.3 days for egg, 8.0 days for larva, 8.4 days for pupa, and 18.7 days for egg-adult.

The larval and pupal survival of $\boldsymbol{L}$. sativae on melon was $95.0 \%$ and $78.2 \%$, respectively. This larval survival was higher than the observed by COSTA-LIMA et al. (2009) for $\boldsymbol{L}$. sativae on $\boldsymbol{V}$. unguiculata (84.8\%) and the pupal survival was similar (78.8\%). Literature presents a large variation on survival of larvae and pupae of Liriomyza (LEIBEE, 1984; LANZONI et al., 2002). However, worth pointing out that many biotic and abiotic factors can influence the survival rates of larvae and pupae (PARRELLA, 1987), like for example, the host plant. The observed sex ratio (0.51) is in accordance with the pattern of the genus Liriomyza, to which PARRELLA (1987) related to be 1:1 in most cases, sometimes having a bias in favor of females.

Regarding to adult longevity, we verified that females live longer than males. While females live in average $19.3 \pm 1.09$ days, males live $16.2 \pm 0.96$ days and have a lower survival probability (Figure 1). According PARRELLA (1987), in general, females live approximately 15 to 20 days in average, and males live 10 to 15 days. However, the author highlights that the food source and the interval in which larva turns to pupa, may influence adult longevity. 


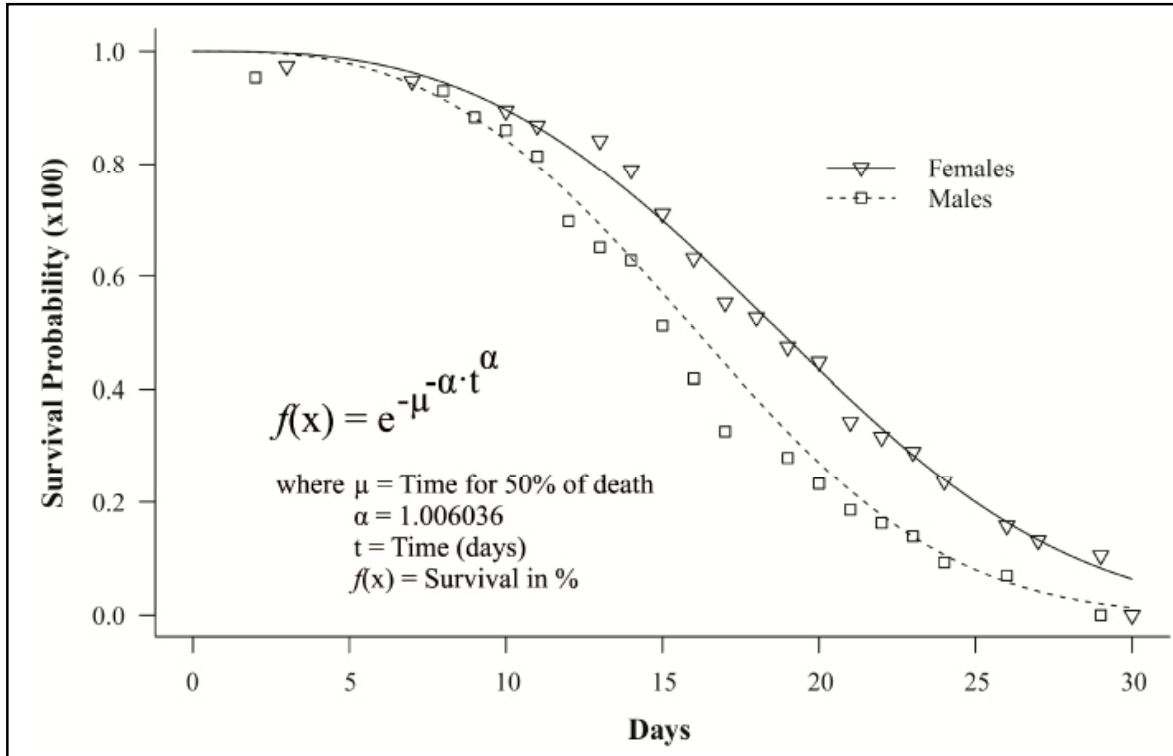

Figure 1 - Weibull distribution for survival probability of males and females of $\boldsymbol{L}$. sativae, reared under $25^{\circ} \mathrm{C}$ on melon plants.

The information presented herein (duration of immature stages, adult longevity, survival) for $\boldsymbol{L}$. sativae in melon, constitute important tools for the adoption of control procedures, aiming at a better integrated management of this pest on melon crop.

\section{REFERENCES}

ARAUJO, E.L. et al. Mosca minadora associada à cultura do meloeiro no semi-árido do Rio Grande do Norte. Revista Caatinga, v.20, n.3, p.210-212, 2007a. Available from: <http:// periodicos.ufersa.edu.br/revistas/index.php/sistema/article/ view/482/180>. Accessed: Abr. 25, 2012.

ARAUJO, E.L. et al. Técnica de criação da mosca minadora Liriomyza trifolii (Burgess) (Diptera: Agromyzidae). Campo Digital, v.2, n.1, p.22-26, 2007b. Available from: <http:// revista.grupointegrado.br/revista/index.php/campodigital/article/ view/317/149>. Accessed: Jun. 10, 2012.

BUENO, A.F. et al. Serpentine leafminer (Liriomyza trifolii) on potato (Solanum tuberosum): field observations and plant photosynthetic responses to injury. Ciência Rural, v.37, n.6, p.1510-1517, 2007. Available from: <http://www.scielo.br/pdf/ cr/v37n6/a01v37n6.pdf>. Accessed: May 10, 2012. doi: 10.1590/ S0103-84782007000600001.

COSTA-LIMA, T.C. et al. Efeito da temperatura e umidade relativa do ar no desenvolvimento de Liriomyza sativae Blanchard (Diptera: Agromyzidae) em Vigna unguiculata. Neotropical Entomology, v.38, n.6, p.727-733, 2009. Available from: <http:// www.scielo.br/pdf/ne/v38n6/04.pdf>. Accessed: May 07, 2012. doi: 10.1590/S1519-566X2009000600004.
COSTA-LIMA, T.C. et al. Reproductive activity and survivorship of Liriomyza sativae (Diptera: Agromyzidae) at different temperatures and relative humidity levels. Environmental Entomology, v.39, n.1, p.195-201, 2010. Available from: <http:// esa.publisher.ingentaconnect.com.ez13.periodicos.capes.gov. br/content/esa/envent/2010/00000039/00000001/art00023>. Accessed: Jun. 10, 2012. doi: 10.1603/EN09209.

IBGE. Produção agrícola. Available from: <http://www.ibge. gov.br/home/>. Accessed: Abr. 12, 2012.

LANZONI, A. et al. Comparative life history of Liriomyza trifolii and Liriomyza huidobrensis (Diptera: Agromyzidae) on beans: effect of temperature on development. Environmental Entomology, v.31, n.5, p.797-803, 2002. Available from: <http://www.bioone.org.ez13.periodicos.capes.gov.br/doi/ pdf/10.1603/0046-225X-31.5.797>. Accessed: May 25, 2012. doi: 10.1603/0046-225X-31.5.797.

LEIBEE, G.L. Influence of temperature on developmentand fecundity of Liriomyza trifolii (Burgess) (Diptera: Agromyzidae) on celery. Environmental Entomology, v.13, n.2, p.497-501, 1984. Available from: <http://esa.publisher.ingentaconnect.com.ez13.periodicos. capes.gov.br/content/esa/envent/1984/00000013/00000002/ art00031>. Accessed: Jun. 10, 2012.

MILLER, G.W.; ISGER, M.B. Effects of temperature on the development of Liriomyza trifolii (Burgess) (Diptera: Agromyzidae). Bulletin of Entomological Research, v.75, n.2, p.321-28, 1985 . Available from: <http://journals. cambridge.org.ez13.periodicos.capes.gov.br/action/displayAbst ract fromPage $=$ online $\&$ aid $=2382652 \&$ fulltext Type $=$ RA \& fileId $=$ S0007485300014413 $>$. Accessed: May 09, 2012. doi: 10.1017/ S0007485300014413. 
MURPHY, S.T.; LaSALLE, J. Balancing biological control strategies in the IPM of new world invasive Liriomyza leafminers in field vegetable crops. Biocontrol News and Information, v.20, n.3, 1999. Available from: <http://www.cabdirect.org/ abstracts/20063049831>. Accessed: Jun. 03, 2012.

PARRELLA, M.P. Biology of Liriomyza. Annual Review of Entomology, v.32, p.201-224, 1987. Available from: <http://www. annualreviews.org.ez13.periodicos.capes.gov.br/doi/pdf/10.1146/ annurev.en.32.010187.001221>. Accessed: Jun. 10, 2012. doi: 10.1146/annurev.en.32.010187.001221

PARRELLA, M.P. Effect of temperature on oviposition, feeding and longevity of Liriomyza trifolii (Diptera: Agromyzidae).
Canadian Entomologist, v.116, p.85-92, 1984. Available from: <http://pubs.esc-sec.ca/doi/pdf/10.4039/Ent11685-1〉. Accessed: Jun. 10, 2012. doi: 10.4039/Ent11685-1.

PRANDO, H.F.; CRUZ, F.Z. Aspectos da biologia de Liriomyza huidobrensis (Blanchard, 1926) (Diptera: Agromyzidae) em laboratório. Anais da Sociedade Entomológica do Brasil, v.15, n.1, p.77-88, 1986.

SCHUSTER, D.J.; PATEL, K.J. Development of Liriomyza trifolii (Diptera: Agromyzidae) larvae on tomato at constant temperatures. Florida Entomologist, v.68, n.1, p.158-61, 1985. Available from: <http://www.jstor.org/stable/3494340>. Accessed: Jun. 10, 2012 